\title{
Increasing nitrogen limitation during summer in the List Tidal Basin (Northern Wadden Sea)
}

\author{
Martina Loebl · Franciscus Colijn • \\ Justus E. E. van Beusekom
}

Received: 17 June 2007 / Revised: 23 July 2007 / Accepted: 13 August 2007 / Published online: 24 November 2007

(C) Springer-Verlag and AWI 2007

\begin{abstract}
The European Wadden Sea is characterized by high nutrient loads and turbid waters. Riverine nutrient input showed a gradual decrease since the mid 1980s. In the List Tidal Basin (Northern Wadden Sea) the frequency of low $\mathrm{NO}_{3}$ values in summer has increased and decreasing mean annual suspended matter concentrations indicate an increasing underwater irradiance. We used an approach developed by Cloern (Aquat Ecol 33:3-16, 1999) to analyze resource limitation of nitrogen (DIN) and underwater irradiance for phytoplankton growth in the List Tidal Basin between 1985 and 2005. Comparing our results to other studies suggests that the List Tidal Basin is one of the most nitrogen sensitive areas of the European Wadden Sea. In 2005, phytoplankton growth was light limited from January to May and in November and December, co-limited by both resources in June, July and October, and nitrogen limited in August and September. Comparing phytoplankton growth limitation in the periods 1985-1991 and 1999-2005, the duration of nitrogen limitation during summer is significantly longer in the second period ( $2.1 \pm 0.9$ months) than in the first $(0.7 \pm 0.5)$. Moreover, light limitation in September and October has decreased in the second period. A decreasing phytoplankton growth during summer is in line with former studies from the List Tidal Basin, which showed that summer chlorophyll concentrations have
\end{abstract}

Communicated by J. van Beusekom.

M. Loebl · F. Colijn

Institute for Coastal Research, GKSS,

Max Planck Strasse 1, 21502 Geesthacht, Germany

M. Loebl ( $\square)$ · J. E. E. van Beusekom

Alfred-Wegener-Institute for Polar and Marine Research,

Wadden Sea Station Sylt, Hafenstrasse 43,

25992 List/Sylt, Germany

e-mail: Martina.Loebl@awi.de decreased since the mid 1980s. We suggest that nowadays less food is available for higher pelagic and benthic trophic levels due an increased nitrogen limitation during summer.

\section{Introduction}

The Wadden Sea (North Sea, Europe) is a shallow coastal sea, among others characterized by eutrophic and turbid waters (Postma 1954; Cadée and Hegeman 2002; van Beusekom 2006). The euphotic zone is shallower than in the adjacent North Sea (Aarup 2002). During the twentieth century riverine nutrient loads increased and reached a maximum during the mid 1980s. Since then decreasing riverine nutrient loads lead to a gradual de-eutrophication of the Wadden Sea (e.g. van Beusekom and de Jonge 2002; Cadée and Hegeman 2002; Philippart et al. 2007; van Beusekom 2006). Time series data of the Dutch Wadden Sea document an increase in pelagic primary production in the Marsdiep area until the mid 1990s followed by a gradual decrease to values between 120 and $170 \mathrm{~g} \mathrm{C} \mathrm{m}^{-2}$ year $^{-1}$ from 2000 to 2004 (Philippart et al. 2007). van Beusekom (2005) suggested that primary production in the Wadden Sea is still four to sixfold higher than under pre-industrial conditions.

According to Liebig's Law of the Minimum, plant growth is reduced if one resource is limiting. In the Wadden Sea nitrogen, phosphate, silicate and underwater irradiance are under debate to be limiting factors for phytoplankton growth (Philippart and Cadée 2000; Colijn and Cadée 2003; van Beusekom et al. 2005; Philippart et al. 2007). Former studies on resource limitation (underwater irradiance vs. nitrogen) suggest that light is a major limiting factor for phytoplankton growth during most of the year, and nitrogen limitation may occur from May to September (Colijn and Cadée 2003). 
In this study we analyze the long-term trends of underwater irradiance and dissolved inorganic nitrogen $\left(\mathrm{NO}_{3}+\mathrm{NO}_{2}+\mathrm{NH}_{4}\right)$ as limiting factors for phytoplankton growth in the List Tidal Basin (Sylt-Rømø-Bight) using the approach developed by Cloern (1999). We will focus on nitrogen since no data on phosphate concentration were available before 1999. To date, no studies have been carried out using this approach to detect long-term changes on resource limitation (light/nutrients) in the Wadden Sea. We investigate resource limitation for two periods, 1985-1991 and 1999-2005. Nitrogen loads into the North Sea have decreased since the mid 1980 s at about $2 \%$ per year (van Beusekom et al. 2005). We hypothesize that phytoplankton growth is stronger nitrogen limited in the second period than in the first. Moreover, we discuss potential consequences for the Wadden Sea food web.

\section{Methods}

Study site

The List Tidal Basin (Sylt-Rømø-Bight) is a $405 \mathrm{~km}^{2}$ semi-enclosed basin in the northern part of the Wadden Sea. It is enclosed by the islands Sylt and Røm $\varnothing$ and by causeways connecting both islands to the mainland. The List Tidal Basin is connected to the open North Sea by a single tidal inlet. A detailed description of the area is given in Gätje and Reise (1998). The mean water depth is $2.7 \mathrm{~m}$ (Loebl et al. 2007). Salinity ranges between $\sim 27.5$ during winter and $\sim 31$ in summer. The water column is homogenously mixed throughout of the year, stratification is a very scarce event (Martens, personal communication; unpublished data). Annual phytoplankton dynamics are characterized by winter Chl $a$ concentrations below $10 \mu \mathrm{g} \mathrm{l}^{-1}$, a spring diatom bloom during March/April with Chl $a$ concentrations up to $60 \mu \mathrm{g}^{-1}$, a Phaeocystis globosa bloom in some years during May/June with Chl $a$ concentrations up to $40 \mu \mathrm{g} \mathrm{l}^{-1}$ and summer Chl $a$ concentrations below $10 \mu \mathrm{g} \mathrm{l}^{-1}$ (van Beusekom et al. 2001). The annual pelagic primary production was $146 \mathrm{~g} \mathrm{C} \mathrm{m}^{-2}$ year $^{-1}$, measured in 2004. On annual average the water column is autotrophic indicating a high food supply to the benthos (Loebl et al. 2007).

Data sets of dissolved inorganic nitrogen and suspended matter

Samples for dissolved inorganic nitrogen (DIN) and suspended matter (SPM) were taken twice a week as part of the Sylt long-term time series. Standard methods according to Grasshoff et al. (1983) were used to measure dissolved $\mathrm{NO}_{3}, \mathrm{NO}_{2}$, and $\mathrm{NH}_{4}$. Volumetric suspended matter concen- trations (SPM) were determined gravimetrically on a $0.47 \mu \mathrm{m}$ pore-size Nucleopore filter.

\section{Data sets on irradiance}

Irradiance data were kindly provided by the Deutsche Wetter Dienst, List/Sylt, Germany as hourly measurements of global irradiance from 1985 to 2005 . We multiplied by 0.5 to obtain PAR and converted to mol per $\mathrm{m}^{2}$ per $24 \mathrm{~h}$ based on a conversion factor of $2.77 \times 10^{18}$ to obtain the number of quanta per Joule (according to Morel and Smith, cited in Kirk 1994).

Calculation of growth rate sensitivity to light and nutrients

Cloern (1999) developed a simple model to investigate the dependence of growth rates on light and nutrients. He developed resource limitation maps on the basis of phytoplankton growth rates as a function of light and nutrients. These resource limitation maps were contour plots of the ratio of growth rate sensitivity to light and nutrients $(=\mathrm{R})$ and provide a simple means of assessing the growth constraints on phytoplankton from measurements of mean water column irradiance and nutrient concentration. This index can be used to compare the sensitivity of individual estuaries and shelf seas to changes in nutrient concentration. We used Cloerns model to calculate the ratio of potential limiting resources (light and DIN) in the List Tidal Basin. Dissolved inorganic nitrogen $\left(\mathrm{NO}_{3}+\mathrm{NO}_{2}+\mathrm{NH}_{4}\right)$ concentrations were taken from measurements at the $14 \mathrm{th}$, 15 th or 16 th of each month, or interpolated from measurements nearest to the 15 th. For the calculations of irradiance we altered the procedure of Cloern and took the monthly mean value of the respective month, instead of taking the average from the 3 days around the middle of each month. Suspended matter concentrations (SPM) were transformed into vertical attenuation coefficients, using an empirical conversion of $k=0.4+0.04$ SPM (Loebl 2006) and a mean water depth of $2.7 \mathrm{~m}$ (Loebl et al. 2007). The half-saturation constants $K_{\mathrm{I}}=2.4$ (daily irradiance at which growth rate is half the maximum) and $K_{\mathrm{N}}=1.5$ (for DIN uptake) were taken from Cloern (1999). We analyzed two periods: 1985-1991 and 1999-2005. Since no SPM data were available for the years between both periods; the years 1992 1998 could not be taken into account for this study.

Cloern (1999) suggests that the sensitivity of his analysis is not high enough to determine the exact position of the boundary line between light and nutrient limitation. He suggests that the growth rate sensitivity to light and nutrients $(R)$ within the boundaries of $0.1<R<10$ (compare Fig. 1) can be considered as a region of potential co-limitation by light and nutrients. He suggests that there is no uncertainty about light limitation if $R>10$, or about nutri- 
Fig. 1 Resource limitation map according to Cloern (1999). Diamonds show positions of light and nutrient measurements the List Tidal basin in 1985 (left) and 2005 (right); Numbers above diamonds indicate respective months. Areas of $R>10$ indicate strong light limitation, areas of $R>0.1$ strong nitrogen limitation, and areas of $10>R>0.1$ indicate co-limitation of light and nitrogen
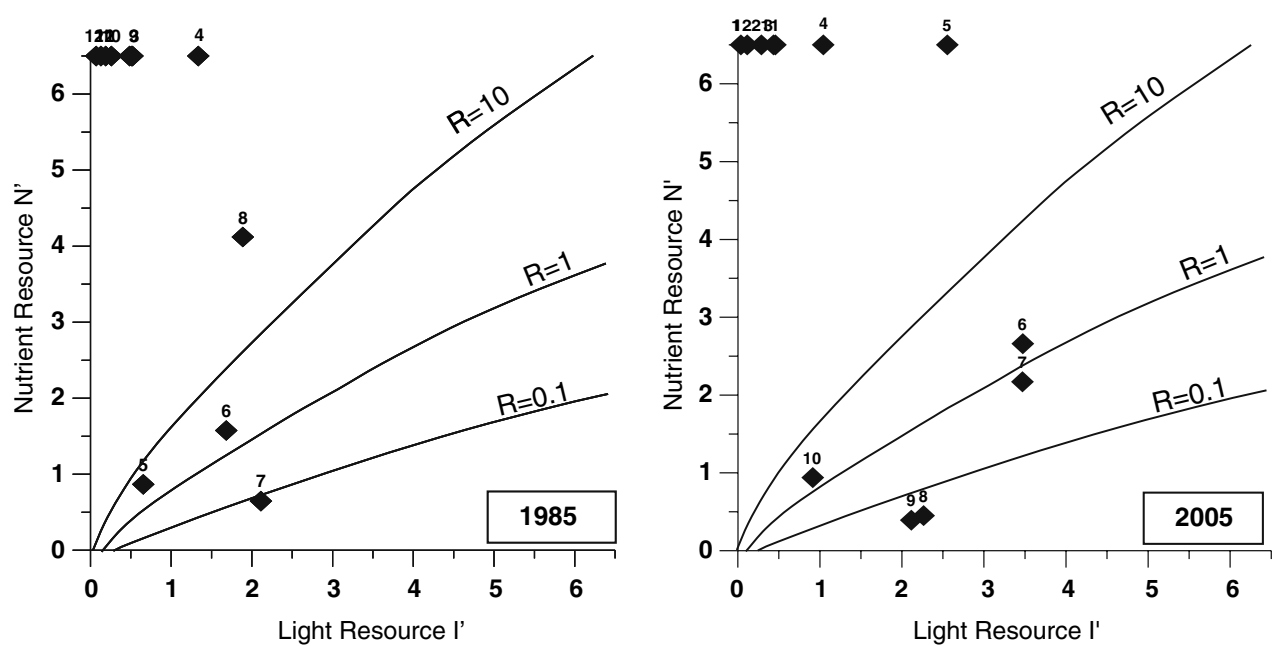

ent limitation if $R<0.1$. We adopted this procedure for the interpretation of our results.

Comparing the period 1985-1991 with the period 1999-2005

We tested whether resource limitation has changed between both periods. We used a $t$ test (Statistica 6.0, Stat Soft) to compare the numbers of months of nitrogen limitation, colimitation and light limitation in period I (1985-1991) and period II (1999-2005). The data were tested for normality using a Kolmogorov-Smirnov test (Statistica 6.0, Stat Soft). We calculated the frequency of occurrence (\%) of each limitation type for July, August, September, and October during each period.

\section{Results}

Dissolved inorganic nitrogen and suspended matter in the List tidal basin showed the following seasonal pattern: During winter, high DIN concentrations prevailed (40$60 \mu \mathrm{mol} \mathrm{l}^{-1}$; compare van Beusekom et al., this volume). In spring DIN decreases until values below $1 \mu \mathrm{mol}^{-1}$ were reached between June and August. DIN remained low until the beginning of September, then increased again and reached its winter maximum during January/February of the following year (e.g. van Beusekom et al. 2001). Suspended matter concentrations ranged between $\sim 1$ and $60 \mathrm{mg}^{-1}$, with highest concentrations during autumn and winter and lowest values during summer.

Sensitivity of phytoplankton growth to light and nutrients

In Fig. 1 we show the annual dynamics of resource limitation in the List Tidal basin in 1985 and in 2005 using the resource limitation map of Cloern. We adopted the interpretation of the model results made by Cloern (1999) where he defined $R>10$ as light limitation, $0.1<R<10$ as co-limitation and $R<0.1$ as nutrient (nitrogen) limitation. In his study, Cloern investigated nitrogen limitation, but suggests that the method can be used for Phosphate and Silicate, too by using the respective half-saturation constants. In our study we investigated long-term changes of light and nitrogen limitation. In 1985, the List Tidal Basin was nitrogen limited in July, co-limited by light and nitrogen in May and June and light limited during all other months. In 2005 the List Tidal Basin was nitrogen limited in August and September, in June, July and October co-limited by both resources and in all other months light limited. Figure 2 shows the resource limitation for all investigated years. We observed high interannual variations in spring where the system shifted from light limitation to nitrogen limitation (May-July) and in autumn, where the system shifted from nutrient to light limitation (July-October) (Fig. 2).

A comparison of both periods indicates that in the first period (1985-1991), the phytoplankton growth during summer was co-limited by both resources and hardly showed strong nitrogen limitation. In the second period (19992005), strong nitrogen limitation during spring/summer occurred nearly each year, apart from 1999 (Fig. 2). The period of strong nitrogen limitation during summer has significantly increased $(P<0.05, n=7)$ from $0.7( \pm 0.5)$ months to $2.1( \pm 0.9)$ months (Fig. 3). The time span of colimitation and strong nitrogen limitation has also significantly increased $(P<0.05, n=7)$ from $2.6( \pm 1.1)$ months to $3.9( \pm 0.9)$ months. The frequency of strong nitrogen limitation in July, August and September has increased in the second period and in October the frequency of strong light limitation decreased in the second period (Fig. 4). Thus, a shift in limitation pattern has occurred from light to nutrient (nitrogen) limitation in summer and autumn. 
Fig. 2 Light- and nutrient limitation in the List Tidal Basin in the periods 1985-1991 and 1999-2005. The contour plot displays the gradients from strong light limitation (dark grey shadings) to strong nutrient limitation (white). The continuous lines represent the boundary lines between strong light limitation and co-limitation. The broken lines represent the boundary between co-limitation and strong nitrogen limitation
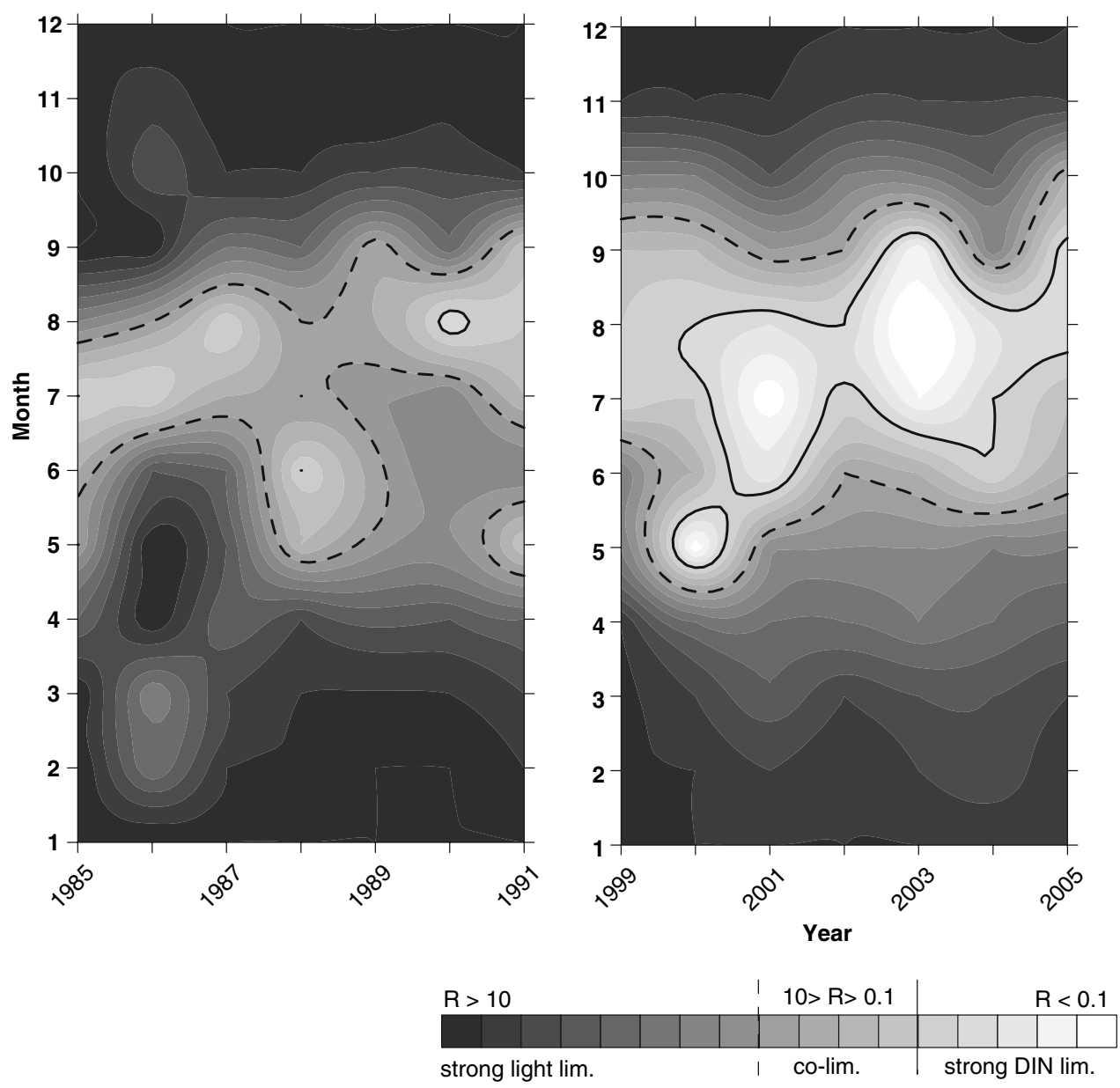

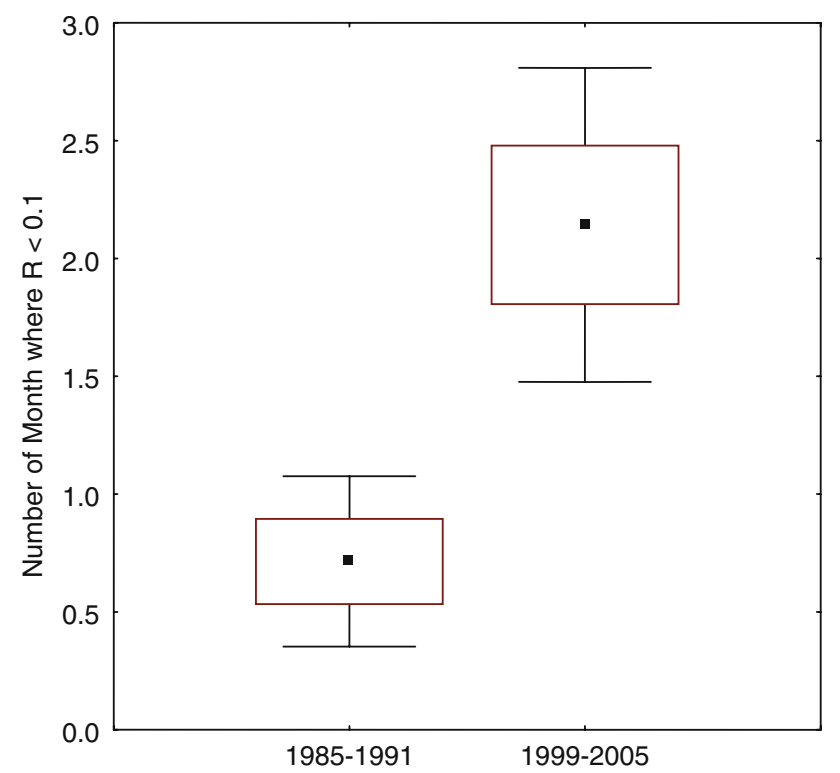

Fig. 3 Number of months in each period with phytoplankton growth strongly nitrogen limited $(R<0.1)$. The occurrence per year is significant longer in 1999-2005 ( $t$ test, $P<0.05, n=7$ ) than in 1985-1991

\section{Discussion}

A loss in functional diversity within the past 1,000 years has homogenized the food-web structure in the Wadden Sea, in particular due to the extinction of large fish, mammals, water birds and specialists on all trophic levels. Food-web control probably shifted from a former top-down control by consumers to a bottom-up control by resource availability (Lotze et al. 2005; van Beusekom 2005). During the past fifty years the riverine nutrient discharges from catchment areas into the Wadden Sea drastically changed due to anthropogenic impact, and implications for coastal food webs were frequently discussed (e.g. de Jonge et al. 1996, Philippart et al. 2007). We investigated the phytoplankton growth limitation by light and nitrogen in the List Tidal Basin since the mid 1980s when riverine nutrient loads started to decrease. We could show that nitrogen limitation has increased during the past twenty years. At present nitrogen is limiting for a period of 2-3 months in summer. In the following we compare our results with other studies and discuss ecological consequences of increased nitrogen limitation on pelagic and benthic food webs. 
Fig. 4 Columns show the frequency $(\%)$ of strong light limitation, co-limitation, and strong nutrient limitation in different months of Period I (1985-1991) and Period II (1999-2005). A frequency of $100 \%$ indicates an occurrence in all years of one period $(n=7)$
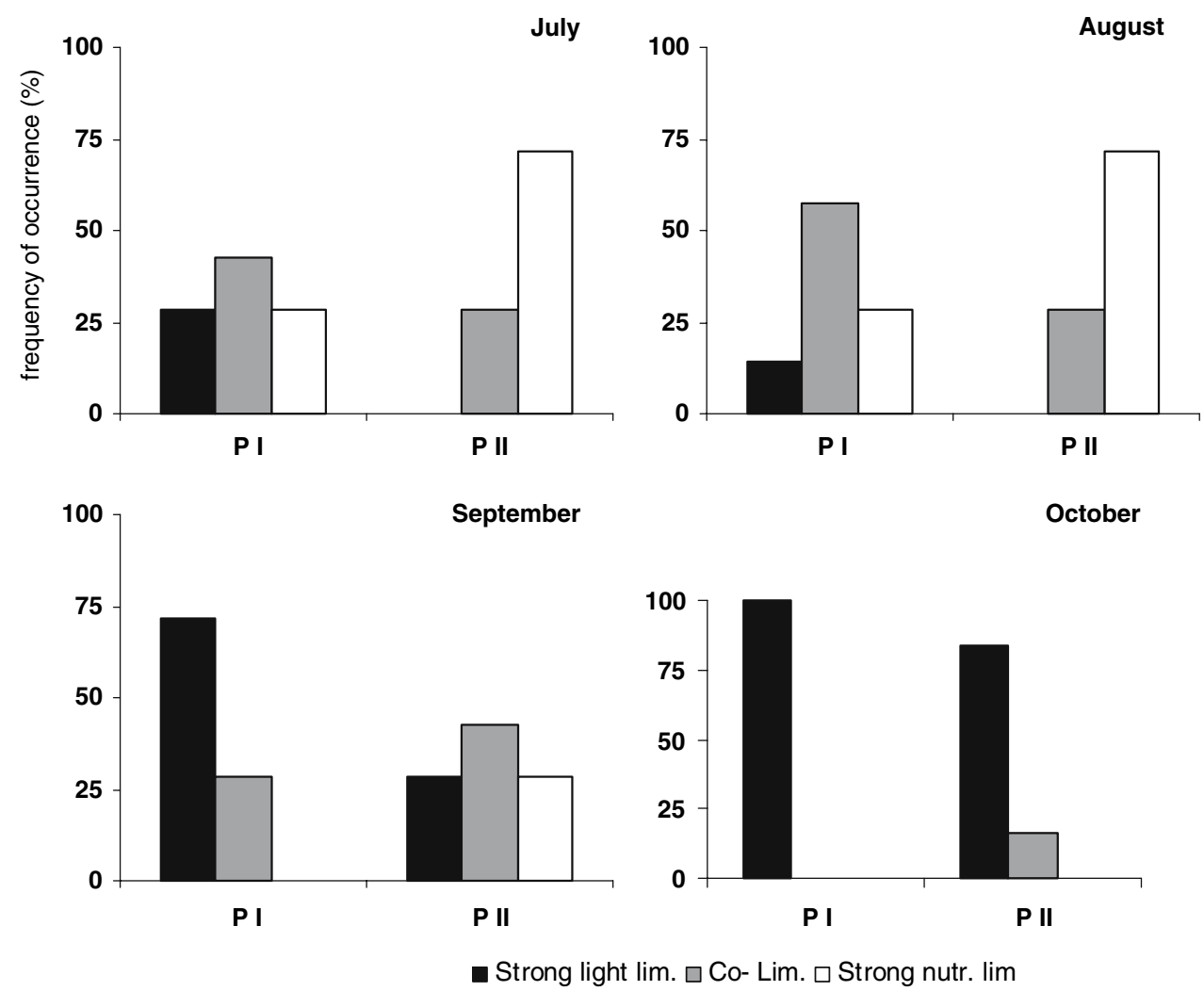

- Strong light lim. $\square$ Co- Lim. $\square$ Strong nutr. lim
Nitrogen sensitivity of phytoplankton growth in the List Tidal Basin

At present phytoplankton growth in the List Tidal Basin is light limited in autumn/winter and strongly nitrogen limited for a period of 2-3 months in summer. In spring and autumn light and nitrogen are co-limiting for a period of 12 months. Comparing our results to other studies indicates that the extent of nitrogen limitation in the List Tidal Basin is higher than in other European coastal zones: Nitrogen limitation in the List Tidal Basin in 2005 was comparable to the Oosterschelde in 1991 (Cloern 1999), and slightly higher than in Norderney in 1990 (Colijn and Cadée 2003). Other investigated areas of the Wadden Sea, the Westerschelde in 1991 (Cloern 1999), the Ems-Dollard Estuary (inner and outer station) in 1994, Büsum Mole in 1994 and the Marsdiep in 1995/1996 (Colijn and Cadée 2003) were clearly less nitrogen and more light limited. Since winter nitrogen values are in a similar range in all Wadden Sea regions (van Beusekom 2006), we assume this longer period of nitrogen limitation and co-limitation to be a result of clearer waters and lower nitrogen loads during the growing season in the List Tidal Basin (Tillmann et al. 2000; Cadée and Hegeman 2002; Aarup 2002). Clearer waters could have facilitated the phytoplankton growth so that nitrogen depleted for a longer time span. Nevertheless, this comparison lacks actual investigations for the other areas, where nitrogen limitation also might have increased over the past $10-15$ years.

Changes of phytoplankton growth limitation within the past 20 years

Our study firstly investigates long-term changes of resource limitation in the Northern Wadden Sea. Comparing Period I (1985-1991) and Period II (1999-2005), nitrogen limitation during summer has increased and light limitation in autumn commences later (Figs. 2, 4). Thus, a shift in limitation pattern has occurred from light to nutrient (nitrogen) limitation in summer and autumn. Less light limitation in autumn presumably extends the phytoplankton growing season. Nutrients depleted more early and for a longer time span. van Beusekom et al. (in preparation) show that in the List Tidal basin the frequency of low nitrogen concentrations $\left(<0.5 \mu \mathrm{M}^{-1}\right)$ during summer has increased since the mid 1980s. Moreover, the increase of nitrogen in autumn has switched from the end of August to the end of September during the past twenty years (J. E. E. van Beusekom, unpublished data) and indicates an extended phytoplankton growing season. This is accompanied by increased late autumn $\mathrm{NH}_{4}+\mathrm{NO}_{2}$ values (van Beusekom 2006) indicating a higher late autumn organic matter turnover due to a longer primary production season. 
A causal relationship between this changed resource limitation pattern and one resource (underwater irradiance or nitrogen) cannot be made, since they result from the ecological interaction between both factors: The Wadden Sea imports particles from the North Sea (Postma 1981, 1982) with the import of organic material being positively related with riverine nitrogen discharge (van Beusekom and de Jonge 2002). The de-eutrophication process might indirectly improve the water transparency of North Sea and Wadden Sea waters: Mc Quatters-Gallop et al. (2007) report that North Sea waters became clearer since the 1980s. This improvement of water transparency has also been observed for the Western Wadden Sea (de Jonge et al. 1996) and the Marsdiep (Cadée and Hegeman 2002). Phosphate is under debate as limiting factor for phytoplankton growth in the Wadden Sea, too (Philippart and Cadée 2000, Philippart et al. 2007). Since no time series data on phosphate were available between 1991 and 1998, we made this analysis only for nitrogen. However, low concentrations measured in the following years indicate that temporarily phytoplankton growth might be limited also by phosphate and/or silicate.

Ecological implications of an increasing nitrogen limitation during summer

Beukema et al. (2002) analyzed time series data from 1970 to 2000 from the Marsdiep tidal inlet (Dutch Wadden Sea) and could show that annual mean values of chlorophyll concentration were significantly correlated with the mean numerical density and biomass of zoobenthos. They found a two to threefold increase in chlorophyll and zoobenthic biomass from the 1970s to the mid 1980s as a result of eutrophication, indicating that food was formerly limiting the zoobenthic biomass. A subsequent nutrient reduction affected the biomasses of both communities to a much lesser extent. Philippart et al. (2007) assume that this weak coupling between nutrient concentrations and zoobenthic biomasses during the reduction phase is due to a delayed response and concurrent changes in size structure, feeding modes and species composition in the zoobenthos. They found a more strongly correlation between variations in limiting nutrients and community structures of phytoplankton, macrozoobenthos and estuarine birds, concluding, that policies aimed on fishery management, bird conservation and nutrient reduction should be aware of trophic relationships affecting the whole ecosystem.

In the List Tidal Basin phytoplankton is highly important for both the pelagic and the benthic food web (Baird et al. 2004; Loebl 2006). A decreased phytoplankton growth in summer may have important ecological implications by leading to decreased growth rates in consumers like herbivorous zooplankton and benthic filter feeders: during summer more than $50 \%$ of the phytoplankton stand- ing stock was transferred by zooplankton grazing into the pelagic food web (Loebl 2006). Benthic suspension and filter feeders like Mya arenaria, mussels (Mytilus edulis), oysters (Crassostrea gigas), cockles (Cerastoderma edule) and polychaetes, e.g. lugworms (Arenicola marina) are dominant benthic inhabitants of the study area (Reise and Lackschewitz 1998; Diederich 2005). They act as sinks for large amounts of organic carbon, including phytoplankton biomass (Asmus et al. 1998; Asmus and Asmus 1991). Food limitation of benthic suspension feeders has, despite for mussels (Asmus 1987), not been proven for the List Tidal Basin. However, a food web analysis in the List Tidal Basin by Baird et al. (2004) showed that phytoplankton production is too low to fuel the pelagic and benthic carbon turnover and additional organic carbon needs to be imported from North Sea waters. We suggest that decreased phytoplankton growth rates during summer lead to decreased growth rates of benthic deposit and suspension feeders of the List Tidal Basin. van Beusekom (2006) showed for the List Tidal Basin that summer chlorophyll concentrations have decreased since the mid 1980s and were positively correlated to riverine nutrient discharge. The phytoplankton species composition in the List Tidal Basin showed no noticeable changes during the last twenty years (J. E. E. van Beusekom, unpublished data). Thus, lower phytoplankton growth rates were not accompanied by a shift in the quality as food resource. This reduced phytoplankton growth during summer cannot be balanced by the extended phytoplankton growing season in autumn since low irradiances depress the autumn primary productivity (Loebl et al. 2007).

\section{Conclusions}

At present, phytoplankton growth in the List Tidal Basin is nitrogen limited for a period of 2-3 month in summer and co-limited by both, nitrogen and light for another 23 months during spring and autumn. Since the mid 1980s nitrogen limitation during summer has increased and less light limitation in autumn presumably extends the phytoplankton growing season. A causal relationship between changed resource limitation and one resource (nitrogen or light) can hardly be made since clearer waters might also be a result of the de-eutrophication process. A comparison with other studies suggests that the List Tidal Basin may be more nitrogen limited than other European coastal zones. Stronger nitrogen limitation during summer reducing the phytoplankton growth is in accordance with decreased summer chlorophyll concentrations in the List Tidal Basin (van Beusekom 2006). Compared to the mid 1980s it appears likely that less phytoplankton is available for higher pelagic and benthic trophic levels during summer. 
Acknowledgments Gerhard Cadée and Peter Martens gave helpful comments on this manuscript for that we were very grateful. We thank Karsten Reise for interesting discussions and insights on the benthic community structure of the List Tidal Basin.

\section{References}

Aarup T (2002) Transparency of the North Sea and Baltic Sea-a Secchi depth data mining study. Oceanologia 44:323-337

Asmus H (1987) Secondary production of an intertidal mussel bed community related to its storage and turnover compartments. Mar Ecol Prog Ser 39:251-266

Asmus RM, Jensen MH, Murphy D, Doerffer R (1998) Primary production of microphytobenthos, phytoplankton and the annual yield of macrophytic biomass in the Sylt- Røm $\varnothing$ Wadden Sea. In: Gätje C, Reise K (eds) Ökosystem Wattenmeer. Springer, Berlin

Asmus RM, Asmus H (1991) Mussel beds: limiting or promoting phytoplankton? J Exp Mar Biol Ecol 148:215-232

Baird D, Asmus H, Asmus R (2004) Energy flow of a boreal intertidal ecosystem, the Sylt- Rømø Bight. Mar Ecol Prog Ser 279:45-61

Beukema JJ, Cadée GJ, Dekker R (2002) Zoobenthic biomass limited by phytoplankton abundance: evidence from parallel changes in two long-term data series in the Wadden Sea. J Sea Res 48:111-125

Cadée GC, Hegeman J (2002) Phytoplankton in the Marsdiep at the end of the 20th century; 30 years monitoring biomass, primary production and Phaeocystis blooms. J Sea Res 48:97-110

Cloern JE (1999) The relative importance of light and nutrient limitation of phytoplankton growth: a simple index of coastal ecosystem sensitivity to nutrient enrichment. Aquat Ecol 33:3-16

Colijn F, Cadée GC (2003) Is phytoplankton growth in the Wadden Sea light or nitrogen limited? J Sea Res 49:83-93

De Jonge VN, Bakker JF, Van Stralen MR (1996) Possible change in the contribution of the river Rhine and the North Sea to the eutrophic status of the western Dutch Wadden Sea. Neth J Aquat Ecol 30:27-39

Diederich S (2005) Differential recruitment of introduced Pacific oysters and native mussels at the North Sea coast: coexistence possible? J Sea Res 53:269-281

Gätje C, Reise K (1998) Ökosystem Wattenmeer. Springer, Berlin

Grasshoff K, Erhardt M, Kremling K (1983) Methods of Seawater analysis. Verlag Chemie Weinheim, New York

Kirk JTO (1994) Light and photosynthesis in aquatic ecosystems. Cambridge University Press, Cambridge

Loebl M (2006) Annual dynamics of Pelagic Carbon fluxes in a Tidal lagoon. PhD Thesis. University of Bremen, Germany

Loebl M, Dolch T, van Beusekom JEE (2007) Annual dynamics of pelagic primary production and respiration in a shallow coastal basin. J Sea Res. doi:10.1016/j.seares.2007.06.003
Lotze HK, Reise K, Worm B, van Beusekom J, Busch M, Ehlers A, Heinrich D, Hoffmann RC, Holm P, Jensen C, Knottnerus OS, Langhanki N, Prummel W, Vollmer M, Wolff WJ (2005) Human transformations of the Wadden Sea ecosystem through time: a synthesis. Helgol Mar Res 59:84-95

Mc Quatters-Gallop A, Raitsos DE, Edwards M, Pradhan Y, Mee LD, Lavender SJ, Attrill MJ (2007) A long-term chlorophyll data set reveals regime shift in North Sea phytoplankton biomass unconnected to nutrient trends. Limn Ocean 52:635-648

Postma H (1982) Hydrography of the Wadden Sea: movements and properties of water and particular matter. Final report of the section "Hydrography" of the Wadden Sea Working Group. Leiden, The Netherlands

Philippart CJM, Cadée GC (2000) Was total primary production in the western Wadden Sea stimulated by nitrogen loading? Helgol Mar Res 54:55-62

Phillippart CJM, Beukema JJ, Cadee GC, Dekker R, Goedhart PW, van Iperen JM, Leopold MF, Herman PJM (2007) Impacts of nutrient reduction on coastal communities. Ecosystems. doi:10.1007/ s10021-006-9006-7

Reise K, Lackschewitz D (1998) Benthos of the Wadden Sea between the Islands of Sylt and Rømø. In: Gätje C, Reise K (eds) Ökosystem Wattenmeer. Springer, Berlin

Tillmann U, Hesse KJ, Colijn F (2000) Planktonic primary production in the German Wadden Sea. J Plankton Res 22:1277-1298

Van Beusekom JEE, Fock H, De Jong F, Diehl-Christiansen S, Christiansen B (2001) Wadden Sea specific eutrophication criteria. Wadden Sea Ecosyst 14:1-115

Van Beusekom JEE, de Jonge VN (2002) Long-term changes in Wadden Sea nutrient cycles: importance of organic matter import from the North Sea. Hydrobiologia 475/476:185-192

Van Beusekom JEE (2005) A historic perspective on Wadden Sea eutrophication. Helgol Mar Res 59:45-54

Van Beusekom JEE, Bot P, Göbel J, Hanslik M, Lenhart HJ, Pätsch J, Peperzak L, Petenati T, Reise K (2005) Eutrophication. In: Essink K, Dettmann C, Farke H, Laursen K, Lüerssen G, Marenic H, Wiersinga W (eds) Wadden Sea Quality Status Report 2004. Wadden Sea Ecosystem No. 19. Trilateral Monitoring and Assessment Group. Common Wadden Sea Secretariat, Wilhelmshaven, Germany

Van Beusekom JEE (2006) Eutrophication Proxies in the Wadden Sea: regional differences and background concentrations. Proceedings from the 11th Scientific Wadden Sea Symposium, Esbjerg, Denmark, 4-8. April 2005 (NERI Technical Reports; 573). National Environmental Research Institute, Ministry of the Environment, Copenhagen, pp 45-51 